\title{
Influence of upflow velocity on performance and biofilm characteristics of Anaerobic Fluidized Bed Reactor (AFBR) in treating high-strength wastewater
}

\author{
Jalil Jaafari ${ }^{1}$, Alireza Mesdaghinia', Ramin Nabizadeh ${ }^{1}$, Mohammad Hoseini $^{2}$, Hossein kamani ${ }^{3}$ \\ and Amir Hossein Mahvi ${ }^{1,4,5^{*}}$
}

\begin{abstract}
One of the key parameters in Fluidized Bed reactors is the control of biofilm thickness and configuration. The effect of upflow velocity on performance and biofilm characteristics of an Anaerobic Fluidized Bed Reactor was studied in treating Currant wastewater at various loading rates. The reactor used this study was made of a plexiglass column being $60 \mathrm{~mm}$ diameter, $140 \mathrm{~cm}$ height, and a volume of $3.95 \mathrm{~L}$. The results demonstrated that the AFBR system is capable of handling an exceptionally high organic loading rate. At organic loading rates of 9.4 to $24.2\left(\mathrm{~kg} \mathrm{COD} \mathrm{m}^{-3}\right)$ at steady state, reactor performances with upflow velocities of $0.5,0.75$ and $1\left(\mathrm{~m} \mathrm{~min}^{-1}\right)$ were 89.3- 63.4, $96.9-79.6$ and 95 - 73.4 percent, respectively. The average biomass concentration per unit volume of the AFBR (as gVSSatt $\mathrm{L}^{-1}$ expended bed) decreased with the increase of upflow velocity in the range of $0.5-1 \mathrm{~m} \mathrm{~min}^{-1}$ at all applied organic loading rates. The total biomass in the reactor increased with increases in the organic loading rate. The peak biomass concentration per unit volume (as gVSSatt $\mathrm{L}^{-1}$ expended bed) was observed at the bottom part of the reactor, then it droped off slowly towards the top. The biofilm thickness increased from the bottom to the top of the reactor representing a stratification of the media in the AFBR. The bed porosity increased from the bottom to the top of the reactor.
\end{abstract}

Keywords: Biofilm characteristics, Biomass concentration, Anaerobic Fluidized Bed Reactor, Currant wastewater, Upflow velocity

\section{Introduction}

In recent years many alternatives have been performed to treatment of high-strength wastewaters [1-4]. Anaerobic Fluidized Bed Reactors (AFBR) were originally a chemical engineering tool used to perform phase transformations, reactions, and diffusions of various chemicals existing in solid, liquid, and vapor phases. With the concept of maximum diffusion and maximum chemical reaction within a minimum volume in mind, AFBRs have been used in biological wastewater treatment and are utilized in several process configurations [5-7]. The results

\footnotetext{
* Correspondence: ahmahvi@yahoo.com

'School of Public Health, Tehran University of Medical Sciences, Tehran, Iran ${ }^{4}$ Center for Solid Waste Research, Institute for Environmental Research,

Tehran University of Medical Sciences, Tehran, Iran

Full list of author information is available at the end of the article
}

from recent studies have consistently illustrated the technical advantage of the fluidized bed over most other suspended and attached growth biological systems. Typically, in a similar capacity, efficiency of the AFBR can be more than 10 times of the activated sludge system while the total space occupied by AFBR is about 10 percent of the required space for stirred tank in activated sludge process [8]. This is due to the AFBR ability in maintaining high concentration of biomass compared with conventional activated sludge system $\left(40,000 \mathrm{mg} \mathrm{L}^{-1}\right.$ vs. $\left.3000 \mathrm{mg} \mathrm{L}^{-1}\right)$ [9]. Fluidization can overcome operating problems such as bed clogging and high pressure drop, which happen if the media with high surface area used in packed-bed reactor. Another advantage of using media is possibility of elimination of secondary clarifiers [10]. Anaerobic Fluidized bed reactors (AFBR) are high-load wastewater treatment 
systems, which have been studied by numerous authors to treat different industrial wastewaters. For example, this system has been used for treatment of textile wastewater [11], ice-cream wastewater [12], and brewery wastewater [13], winery wastewater from Grape-Red and tropical fruit [14], currant [15] and sanitary landfill leachate [16]. The microbial population is the critical parameter in the performance of biological process that the influenced by operational parameters, physicochemical properties of the carrier material (density, roughness, porosity) on the fixed bed process are critical considerations $[17,18]$. One of the key operational parameters in attached biofilm reactors is the control of biofilm thickness and configuration, and research on biofilm formation and detachment has developed considerably in the past years, although there is no design rule for the rate of detachment. The prediction of biofilm structure (density, porosity, roughness, shape) and thickness is most important in designing and operation of biofilm processes, because hydrodynamics, mass transfer and conversion in biofilm processes depend on these variables. In attached growth process, biofilm accumulation is a dynamic process that is the net result of growth and the detachment processes. This is affected by several external factors, including composition and concentration of the feed, concentration of particles, particle-particle collisions, and particle-wall collisions, and velocity of the liquid phase (shear stress). This is the most important factor influencing formation, structure and stability of biofilms. In a biofilm system, higher hydrodynamic shear force take a stronger biofilm, and the biofilm tends to become a heterogeneous, porous and weaker structure when the shear force is too weak [19-22].

The main objective of this study was to investigate the influence of different upflow velocity on performance and biofilm characteristics of Anaerobic Fluidized Bed Reactor in treating a real Currant wastewater in various HRT and loading rates.

\section{Materials and methods}

\section{Anaerobic Fluidized bed reactor}

The reactor was made of a plexiglass column being $60 \mathrm{~mm}$ diameter, $140 \mathrm{~cm}$ height, and a volume of $3.95 \mathrm{~L}$. The enlarged top section of column was used as a gassolid separator. The enlarged section had diameter of $100 \mathrm{~mm}$ with a volume of $1.48 \mathrm{~L}$ (Figure 1). The bottom of the reactor was flat with symmetrically placed four pores through which flow was equally distributed into the reactor. The column has six sampling ports located at $5,30,55,80,105$ and $130 \mathrm{~cm}$ above the reactor bottom. The recycled flow was drawn from the top section using a Circulator Pump and then fed upward into the reactor. Reactor temperature was controlled by Aquarium Heater at $35 \pm 2^{\circ} \mathrm{C}$. The reactor was loaded with $1.48 \mathrm{~kg}$ media made of PVC with a mean diameter of $2 \mathrm{~mm}$ as a biofilm carrier to a settled depth of $0.6 \mathrm{~m}$. The particles had a specific gravity of 1.45 , a porosity of 0.4 , and a specific surface area of $1800 \mathrm{~m}^{2} \mathrm{~m}^{-3}$. The bed expansion in fluidized bed reactor was $30 \%$ during the start-up period. The expansion of the bed should be determined based on consideration of the minimum fluidization velocity. Some studies have been determined the factors affecting minimum fluidization velocity and maximum pressure drop [23-25]. Also, Peng and Fan [26] developed theoretical models for estimating of minimum fluidization velocity and maximum pressure drop, based on the dynamic balance of forces exerted on the particle. Some of the well known correlations available for predicting the minimum fluidization velocity $(U \mathrm{mf})$ and maximum pressure drop (Pmax) for tapered beds are those by Peng and Fan. The influence of superficial velocity on pressure drop in reactor is illustrated and shown in Figure 2. By increasing upflow velocity to $0.75\left(\mathrm{~m} \mathrm{~min}^{-1}\right)$, pressure drop increased, then, with increasing superficial velocity to more than $0.75\left(\mathrm{~m} \mathrm{~min}^{-1}\right)$, pressure drop remained constant. So, to ensure that the fluidization condition is exist, the superficial velocity should not be less than the minimum fluidization velocity which is $0.75 \mathrm{~m} \mathrm{~min}^{-1}$ in our reactor. Also, upflow velocity in start-up period was adjusted $0.75\left(\mathrm{~m} \mathrm{~min}^{-1}\right)$. After the start-up period, the real Currant wastewater was fed to the reactor and upflow velocities in different organic loading rate were adjusted to $0.5,0.75$ and $1 \mathrm{~m} \mathrm{~min}^{-1}$.

\section{Start-up period}

Anaerobic reactor was seeded with $1 \mathrm{~L}$ of aerobic active sludge obtained from aerobic digesters of municipal wastewater treatment plant with MLSS and MLVSS of 24.84 and $16.9 \mathrm{~g} \mathrm{~L}^{-1}$, respectively. Table 1 is a summary of conditions tested during the start-up. The reactor fed with synthetic wastewater contained methanol, glucose, and Currant wastewater. Some macro and micronutrients such as $\mathrm{CaCl}_{2} \cdot 2 \mathrm{H}_{2} \mathrm{O}\left(50 \mathrm{mg} \mathrm{L}{ }^{-1}\right),\left(\mathrm{NH}_{4}\right)_{2} \cdot \mathrm{HPO}_{4}\left(80 \mathrm{mg} \mathrm{L}^{-1}\right)$, $\mathrm{FeCl}_{2} \cdot 4 \mathrm{H}_{2} \mathrm{O}$ (40 $\left.\mathrm{mg} \mathrm{L}^{-1}\right), \mathrm{NH}_{4} \mathrm{Cl}\left(1200 \mathrm{mg} \mathrm{L}^{-1}\right)$, $\mathrm{Na}_{2} \mathrm{~S} .9 \mathrm{H}_{2} \mathrm{O}\left(300 \mathrm{mg} \mathrm{L}^{-1}\right), \mathrm{CuCl}_{2} \cdot 2 \mathrm{H}_{2} \mathrm{O}\left(0.5 \mathrm{mg} \mathrm{L}^{-1}\right)$, $\mathrm{MgSO}_{4} .7 \mathrm{H}_{2} \mathrm{O}\left(400 \mathrm{mg} \mathrm{L}{ }^{-1}\right), \mathrm{H}_{3} \mathrm{BO}_{3}\left(0.5 \mathrm{mg} \mathrm{L}^{-1}\right)$, $\mathrm{MnCl}_{2} .4 \mathrm{H}_{2} \mathrm{O}\left(0.5 \mathrm{mg} \mathrm{L}^{-1}\right), \mathrm{NaWO}_{4} .2 \mathrm{H}_{2} \mathrm{O}\left(0.5 \mathrm{mg} \mathrm{L}^{-1}\right)$, $\left.\mathrm{AlCl}_{3} \cdot 6 \mathrm{H}_{2} \mathrm{O}\left(0.5 \mathrm{mg} \mathrm{L}^{-1}\right), \mathrm{Na}_{2} \mathrm{SeO}_{3}\left(0.5 \mathrm{mg} \mathrm{L}^{-1}\right), \mathrm{mg} / \mathrm{l}\right)$, $\mathrm{KCl}\left(400 \mathrm{mg} \mathrm{L} \mathrm{L}^{-1}\right), \mathrm{ZnCl}_{2}\left(0.5 \mathrm{mg} \mathrm{L} \mathrm{L}^{-1}\right), \mathrm{NaHCO}_{3}$ (3000 mg L $\left.{ }^{-1}\right), \mathrm{NaMoO}_{4} \cdot 2 \mathrm{H}_{2} \mathrm{O}\left(0.5 \mathrm{mg} \mathrm{L}^{-1}\right), \mathrm{CoCl}_{2} \cdot 6 \mathrm{H}_{2} \mathrm{O}$ $\left(10 \mathrm{mg} \mathrm{L}^{-1}\right)$, KI $\left(10 \mathrm{mg} \mathrm{L}^{-1}\right)$, and $\mathrm{NiCl}_{2} \cdot 6 \mathrm{H}_{2} \mathrm{O}\left(0.5 \mathrm{mg} \mathrm{L}^{-1}\right)$, which are needed for optimal biofilm growth were used. In colonization stage, anaerobic fluidized reactor was run in the batch mode for one week. Then, during the start-up period run in the continuous mode and COD concentration in feed was gradually raised. Also methanol, which included $75 \%$ of the total influent COD, was used in the beginning to encouraging the growth of methanosarcina 


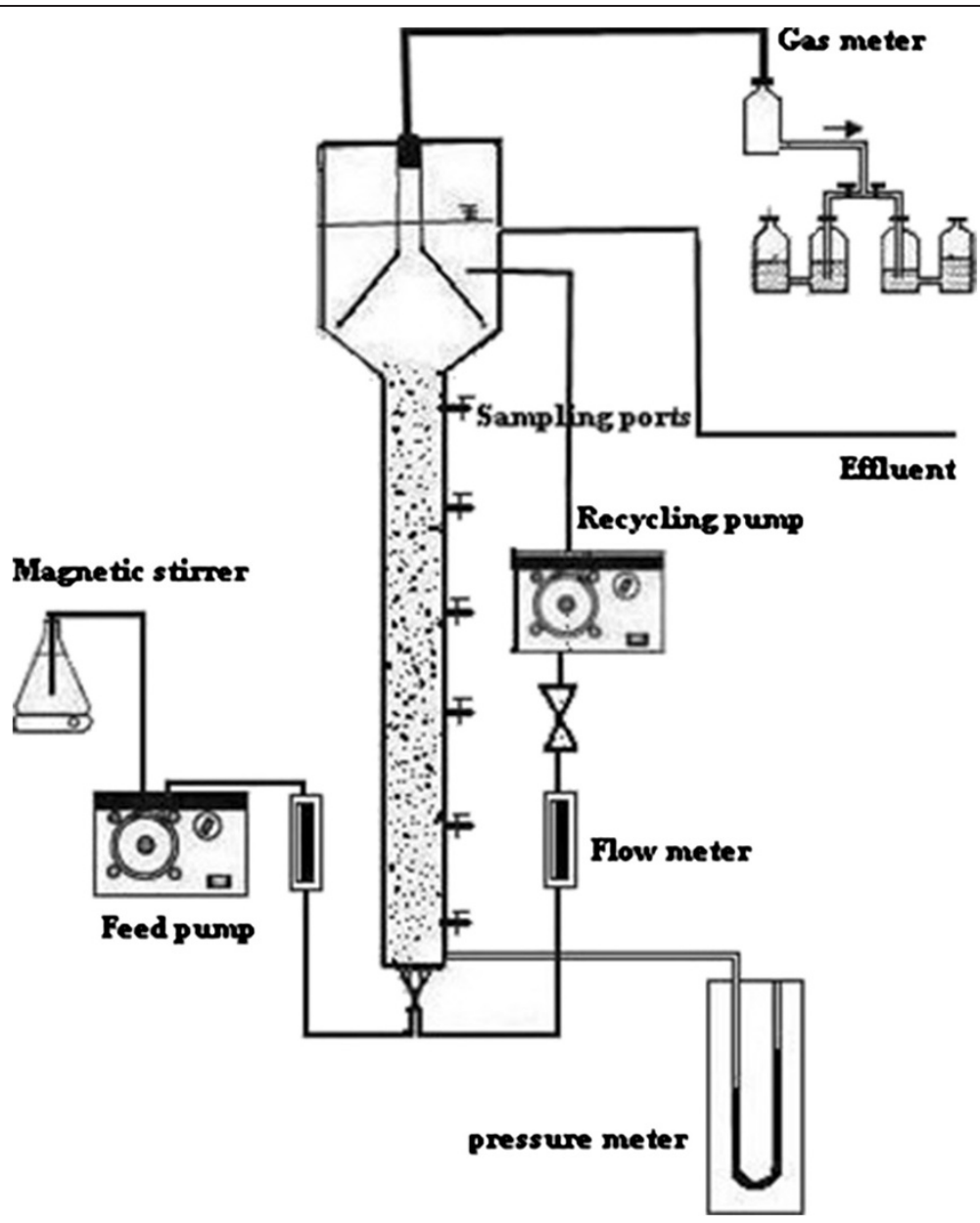

Figure 1 Schematic configuration of Anaerobic Fluidized bed reactor.

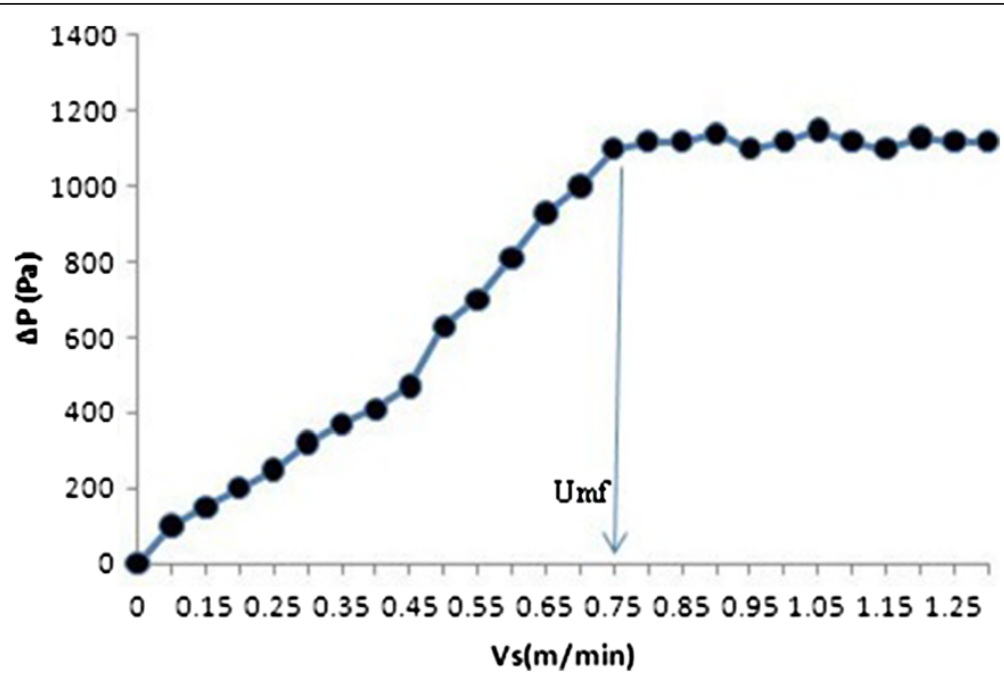

Figure 2 Effect of liquid upflow velocity on pressure drop. 
Table 1 Organic loading and characteristics of fed during the start-up

\begin{tabular}{|c|c|c|c|c|c|}
\hline Time (d) & COD loading $\left(\mathrm{kg} \mathrm{COD} / \mathrm{m}^{3}\right)$ & Methanol a & Glucose a & Currant wastewater a & $\mathrm{NH}_{4} \mathrm{Cl} \mathrm{b}$ \\
\hline $0-10$ & $0.5-4$ & 75 & 25 & 0 & 50 \\
\hline $11-20$ & $4-7$ & 50 & 50 & 0 & 75 \\
\hline $21-30$ & $7-11$ & 25 & 75 & 0 & 100 \\
\hline $31-40$ & $11-13$ & 0 & 75 & 25 & 100 \\
\hline $41-50$ & $13-15$ & 0 & 50 & 50 & 100 \\
\hline $51-60$ & $13-15$ & 0 & 25 & 75 & 100 \\
\hline
\end{tabular}

a- $\%$ of total COD b- $\%$ of its value at the end of the start -up.

bacteria [27]. Then, the percent of methanol in the influent was gradually decreased to $50 \%, 25 \%$, and $0 \%$ in days 11,21 , and 31 , respectively by replacing with glucose and Currant wastewater. Additionally, in the start-up period, $\mathrm{NH}_{4} \mathrm{Cl}$ concentration was gradually increased to taken high $\mathrm{C} / \mathrm{N}$ ratios (1200 mg L-1). Part of this $\mathrm{N}$ with carbon was used by bacteria for building up the new cell to encourage extra cellular polymer production, which aids bacterial attachment on solid surface [28].

\section{Operation period}

In the operational period that lasted $372 \mathrm{~d}$, the Anaerobic Fluidized bed reactor was fed with real Currant wastewater. The real currant wastewater obtained from the factory located in the Safadasht Industrial Zone, Shahriar, Iran, that in Characteristics of Currant wastewater is given in Table 2. The AFBR was operated under five different hydraulic retention times of 48, 40,32, 24 and $18 \mathrm{~h}$, respectively and each of HRT operated under three upflow velocities of $0.5,0.75$ and $1 \mathrm{~m} \mathrm{~min}^{-1}$, respectively.

\section{Analytical methods}

Samples were analyzed for COD according to standard method [29]. Temperature was measured by a thermometer and $\mathrm{pH}$ was measured by a pH-meter (E520 Metrohm Herisau). The biofilm thickness was measured using the method of Schreyer and Coughlin [30], according to the following method. A slurry sample of known volume was smoothly washed to remove the suspended solids and

Table 2 Characteristics of currant wastewater used in the present study

\begin{tabular}{llll}
\hline Parameter & \multicolumn{2}{l}{ Value } & \\
\cline { 2 - 4 } & Range & Average & SD \\
\hline pH Value & $5.2-7.3$ & 6 & 0.7 \\
COD $(\mathrm{mg} / \mathrm{L})$ & $17200-19000$ & 18250 & 447 \\
BOD5 $(\mathrm{mg} / \mathrm{L})$ & $12500-13000$ & 12748 & 185 \\
TSS $(\mathrm{mg} / \mathrm{L})$ & $331-410$ & 365 & 23.3 \\
COD-BOD ratio & 1.45 & - & - \\
Tot-P $(\mathrm{mg} / \mathrm{L})$ & $12-25$ & 18 & 3.8 \\
Tot-N $(\mathrm{mg} / \mathrm{l})$ & $41-86$ & 60 & 13.1 \\
\hline
\end{tabular}

then filtered. The wet bio-particles were carefully removed from the filter into a ceramic dish and weighed to determine its wet mass. After oven-drying for $24 \mathrm{~h}$ at $105^{\circ} \mathrm{C}$, then cooled in a desiccator and weighed. The dried sample was ignited in a $550^{\circ} \mathrm{C}$ furnace for $30 \mathrm{~min}$, cooled in a desiccator and then weighed. The difference between two dried weights would yield the weight of immobilized biomass as attached volatile solids (AVS). Also for ensure the results obtained from the Schreyer and Coughlin procedure, the biofilm thickness was measured using a highresolution microscope equipped with a micrometer [30] method. In comparison of two measurements, the relative error was always less than $10 \%$. The bio-particle density was measured from its settling velocity and diameter of bio-particle [31].

\section{Results and discussion}

The start-up period was completed in $60 \mathrm{~d}$. So, that the feed COD increased stepwise and effluent COD of the anaerobic decreased and the COD removal efficiency gradually increased. In the end of the start-up period, in Anaerobic Fluidized Bed Reactor, attached volatile solid (AVS) concentration reached to 0.0185 gvss g $^{-1}$ which is in accordance with ranges $0.074-0.11$ reported by Farhan et al., 1997 [32], 0.039 [33], 0.05 [34], 0.0732 [27] and $0.0375-0.429$ gvss $^{-1}$ by [35]. Table 3 shows operational parameters obtained at the end of start-up period.

Table 3 Operational parameters obtained at the end of start-up period for AFBR

\begin{tabular}{ll}
\hline Operational parameters & FBR \\
\hline OLR, kg COD/m3 & 15 \\
HRT & 24 \\
Upflow velocity (m/min)CBU & 0.75 \\
Expansion \% & 30 \\
Volume of expanded bed (cm3) & 2210 \\
M support (g) & 1480 \\
VSatt (g) & 27.5 \\
g VSatt/g support & 0.0185 \\
g VSatt/l expanded bed & 11.9 \\
\hline
\end{tabular}




\section{Effect of organic loading rate and upflow velocity on COD removal}

Figure 3 and Table 4 show the effect of the OLR on the COD removal efficiency (E) and COD effluent in reactor throughout the operation time for the reactor studied. As shown, during stage 1, OLR in AFBR was kept at around 9.4 $\mathrm{g} \mathrm{COD} \mathrm{L.d}{ }^{-1}$ with the feed COD concentration of $18,000 \pm 300 \mathrm{mg} \mathrm{L}^{-1}$ and HRT around $48 \mathrm{~h}$, the reactor performance was investigate for $0.5,0.75$ and $1 \mathrm{~m} \mathrm{~min}^{-1}$ upflow velocities. At steady state, with 0.5 , 0.75 and $1 \mathrm{~m} \mathrm{~min}^{-1}$ upflow velocities, the reactor performances in stage 1 were 89.3, 96.6 and 95 percent, respectively. At stage 2, the HRT of reactor was decreased from $48 \mathrm{~h}$ to $40 \mathrm{~h}$ and OLR in Anaerobic Fluidized Bed Reactor increased from 9.4 to $10.8 \mathrm{~g}$ COD L.d $\mathrm{d}^{-1}$ and feed COD concentration was as same as the stage 1 , the reactor performance dropped to $86,95.2$ and 94 percent, respectively. As can be seen, in the stage 1 and 2, in the second set, $0.75 \mathrm{~m} \mathrm{~min}^{-1}$ upflow velocity had more removal efficiency than other upflow velocities. Also In other stages, in the second set, $0.75 \mathrm{~m} \mathrm{~min}^{-1}$ upflow velocity had more removal efficiency than other upflow velocities. In the stage 5 , the OLR was further increased to 24.2 g COD L.d $\mathrm{d}^{-1}$. By decreasing HRT to $18 \mathrm{~h}$, reactor performance dropped to 63.4, 79.6 and 73.4 percent, respectively. The average COD concentration in the effluent of the three sets at a loading rate of $9.4 \mathrm{~g} \mathrm{COD} \mathrm{L.d^{-1 }}$ was 2020, 630 and $940 \mathrm{mg} \mathrm{L}^{-1}$, respectively. Then, the average COD concentration in the effluent of the three sets at a loading rate of 24.2 g COD L.d ${ }^{-1}$ increased gradually to 6515,3666 and $4835 \mathrm{mg} \mathrm{L}^{-1}$, respectively.

Higher biodegrading rates were generally achieved at relatively lower superficial velocities. However there was a minimum practical velocity $\left(0.5 \mathrm{~m} \mathrm{~min}^{-1}\right)$ below which would agglomeration of media occur in the reactor and the anaerobic process might disrupt. Also the subsequent decrease of the fluidization percentage in $0.5 \mathrm{~m} \mathrm{~min}^{-1}$ upflow velocity, which is below the minimum fluidization velocity, might have mass transfer limitations caused by accumulation of fatty acids in the reactor [36]. The substrate utilization rate in the biological process, correlated to diffusion resistance, is strongly dependent on reactor design and mixing intensity [37]. In the third set in Vs of $1 \mathrm{~m} \mathrm{~min}^{-1}$, the reactor performance was lower in compare with the second set with the Vs of $0.75 \mathrm{~m} \mathrm{~min}^{-1}$, because the biofilm was detached and washed out of the system as a result of the increased shearing force and bed porosity. In the treatment of high-strength distillery wastewater by anaerobic fluidized bed reactor with natural zeolite, COD removals of $80 \%$ were achieved at OLR of 20 g COD L.d-1 and HRT of $11 \mathrm{~h}$ [38]. In another study with anaerobic fluidized bed reactor for treating ice-cream wastewater, at an organic COD loading rate of $15.6 \mathrm{~g} \mathrm{~L}-1 . \mathrm{d}$ and HRT of $8 \mathrm{~h}$, COD removal efficiencies of $94.4 \%$ was achieved [12]. In the treatment of thin stillage wastewater using an anaerobic fluidized bed with OLR of 29 g COD L.d-1 and HRT of $3.5 \mathrm{~h}$, COD removal efficiencies of $88 \%$ was achieved [38]. In the stage 1 and 2, with increasing the upflow velocity, COD removal rate due to appropriate mass balance was improved. But, in the stages 3 to 5 , in three set with $0.75 \mathrm{~m} \mathrm{~min}^{-1}$ upflow velocity, Vs was increased due to the decrease in the biomass concentration, which resulted increase in shearing force and increase in bed porosity, while the organic loading rate in the reactor was increasing.

\section{Effect of the upflow velocity and organic loading rate on the biomass concentration}

The effect of the upflow velocity on the average biomass concentration in the AFBR is illustrated by Figure 4. As shown, that the average biomass concentration per unit volume of the AFBR decreased with the increase of the upflow velocity at all of organic loading rate. For example, at OLR of $9.4 \mathrm{~g} \mathrm{COD} \mathrm{L.d}^{-1}$ with HRT of $48 \mathrm{~h}$,

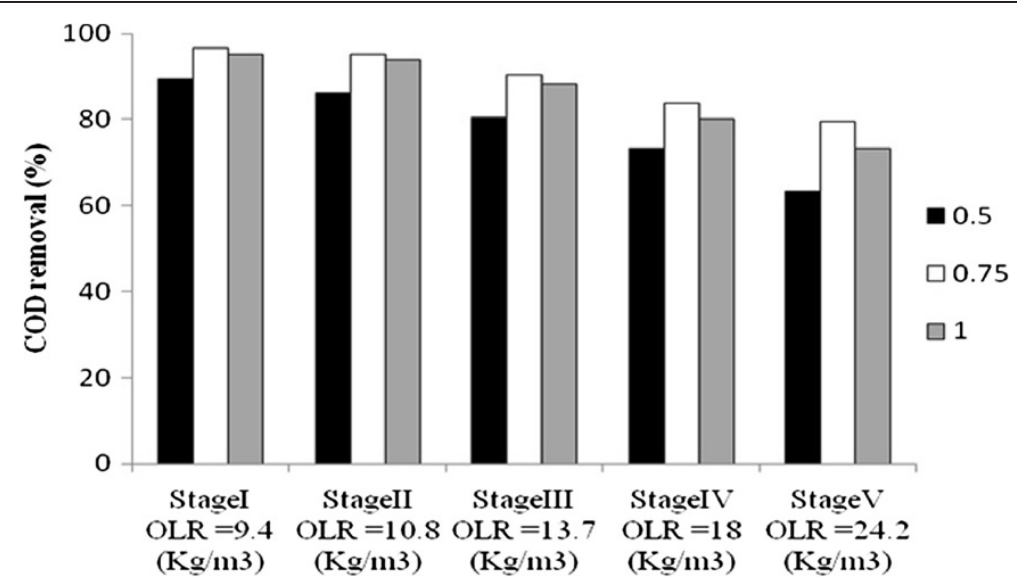

Figure 3 Effect of the upflow velocity and organic loading rate on reactor performance. 
Table 4 Summary of the average results of the three sets of experiments at steady state

\begin{tabular}{|c|c|c|c|c|c|c|c|c|}
\hline Stage & Time (d) & Vs (m/min) & $Q_{\text {in }}(I / d)$ & HRT (h) & OLR (gCOD/l/d) & CODout (mg/l) & $\mathrm{VS}_{\mathrm{att}}(\mathrm{gvs} / \mathrm{l})$ & Expanded bed $(\mathrm{mm})$ \\
\hline \multirow[t]{3}{*}{ I } & $1-18$ & 0.5 & 2.25 & 48 & $9.4 \pm 0.2$ & 2020 & 20.2 & 690 \\
\hline & $19-37$ & 0.75 & 2.25 & 48 & $9.4 \pm 0.2$ & 630 & 15.5 & 790 \\
\hline & $38-61$ & 1 & 2.25 & 48 & $9.4 \pm 0.2$ & 940 & 12.1 & 905 \\
\hline \multirow[t]{3}{*}{$\|$} & $62-78$ & 0.5 & 2.7 & 40 & $10.8 \pm 0.2$ & 1540 & 18.1 & 780 \\
\hline & $79-97$ & 0.75 & 2.7 & 40 & $10.8 \pm 0.2$ & 873 & 13.9 & 885 \\
\hline & $98-118$ & 1 & 2.7 & 40 & $10.8 \pm 0.2$ & 1086 & 11.7 & 945 \\
\hline \multirow[t]{3}{*}{ III } & 119-138 & 0.5 & 3.375 & 32 & $13.7 \pm 0.3$ & 3440 & 17.1 & 835 \\
\hline & $139-163$ & 0.75 & 3.375 & 32 & $13.7 \pm 0.3$ & 1544 & 13.4 & 930 \\
\hline & $164-188$ & 1 & 3.375 & 32 & $13.7 \pm 0.3$ & 1780 & 11.2 & 1000 \\
\hline \multirow[t]{3}{*}{ IV } & $189-210$ & 0.5 & 4.5 & 24 & $18 \pm 0.3$ & 4815 & 16.8 & 870 \\
\hline & $211-238$ & 0.75 & 4.5 & 24 & $18 \pm 0.3$ & 2970 & 13.2 & 955 \\
\hline & $239-267$ & 1 & 4.5 & 24 & $18 \pm 0.3$ & 3650 & 10.8 & 1120 \\
\hline \multirow[t]{3}{*}{ V } & $268-294$ & 0.5 & 5.6 & 18 & $24.2 \pm 0.5$ & 6515 & 16.7 & 905 \\
\hline & 295-326 & 0.75 & 5.6 & 18 & $24.2 \pm 0.5$ & 3666 & 13.18 & 980 \\
\hline & $327-372$ & 1 & 5.6 & 18 & $24.2 \pm 0.5$ & 4835 & 10.8 & 1180 \\
\hline
\end{tabular}

the average biomass concentration decreased from 20.2 to $12.1 \mathrm{~g} \mathrm{VSS} \mathrm{L}^{-1}$, when Vs was increased from 0.5 to $1 \mathrm{~m} \mathrm{~min}^{-1}$. The decrease in the average biomass concentration as a result of the increase in upflow velocity is attributed to two main factors. When, Vs was greater than before, the bed porosity increased, which resulted a lower concentration of bio-particles per unit volume of the AFBR and consequently a lower biomass concentration in volume of reactor. Furthermore, shear forces exerted on the biofilm by the fluid increased. This resulted in a denser and thinner biofilms were formed and consequently resulted in a lower biomass concentration. As shown in Figure 5, it was observed that the average biomass concentration in the AFBR generally decreased with increase in the organic loading rate up to stage 3 , wherever the change of biomass concentration as a function of the organic loading rate became insignificant. As at Vs of $0.75 \mathrm{~m} \mathrm{~min}^{-1}$, the average biomass concentration decreased from 15.5 to 13.2 gvss $\mathrm{L}^{-1}$ expanded bed when the organic loading rate was increased from 9.4 to 10.87 g COD L. $\mathrm{d}^{-1}$, respectively. Then, when the loading rate was increased from 10.87 to 24.2 g COD L.d ${ }^{-1}$, the average biomass concentration accomplished an approximately steady value of 13.18 gvss $\mathrm{L}^{-1}$ expanded bed. Also, similar trend of results was obtained from the other sets of experiments. However, at Vs of $0.5 \mathrm{~m} \mathrm{~min}^{-1}$, the rate of change in the average biomass concentration started to decrease at a higher loading rate (13.72 g COD L.d $\mathrm{d}^{-1}$ ) than that of the other two upflow velocities. The biomass concentration decreases when the organic

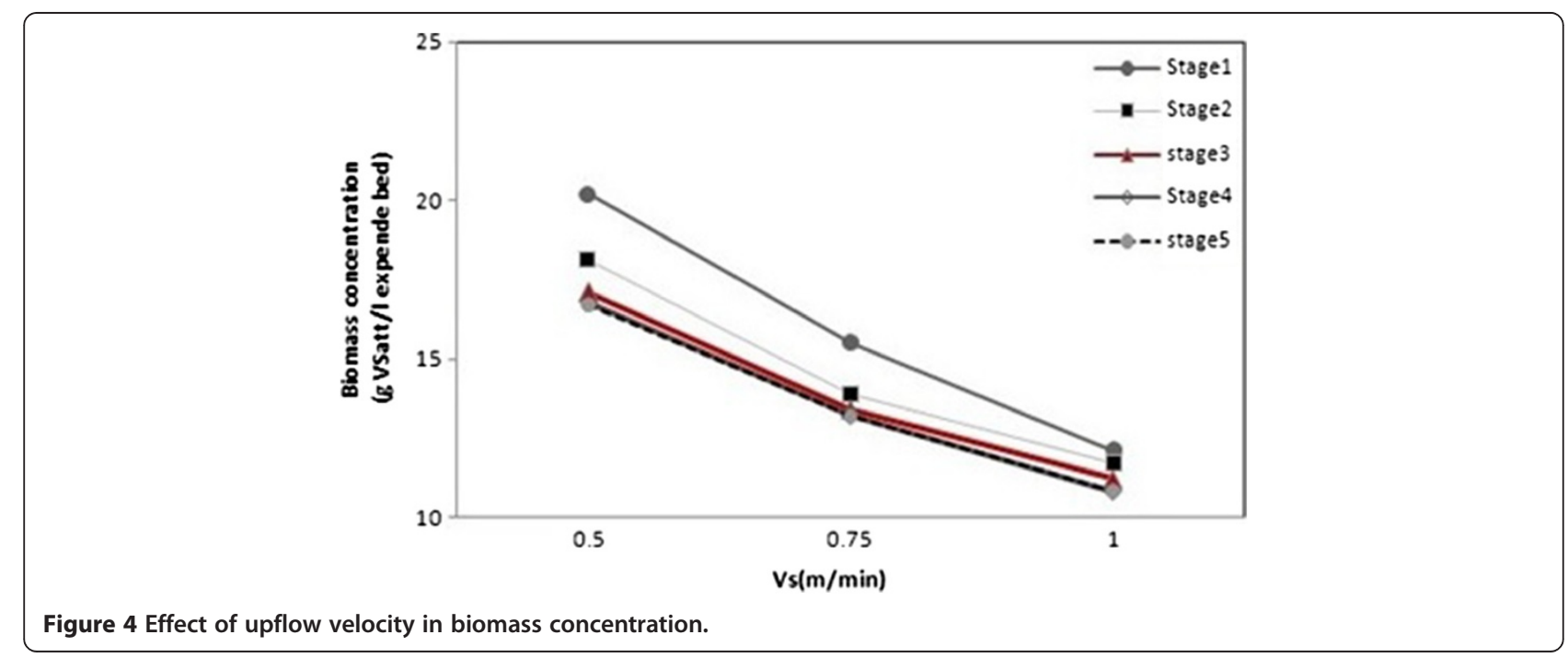




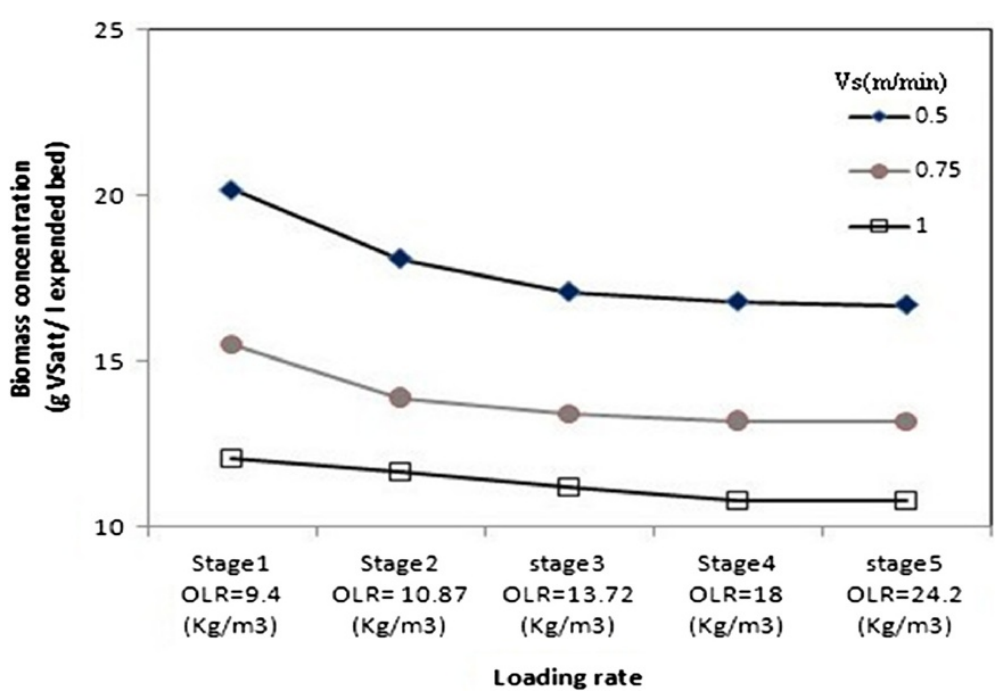

Figure 5 Effect of organic loading rate in biomass concentration.

loading rate increase occurs as a result of the increase in the biofilm thickness due to the increase in the substrate concentration in the bulk liquid [39]. Since, the biofilm thickness increased, the porosity of the AFBR rose, and therefore the average biomass concentration per unit volume of the bed decreased.

\section{Biomass concentration, biofilm thickness and particle density profiles along the AFBR}

Figures 6, 7, and 8 show typical profiles of biomass concentration, biofilm thickness and particle density along the AFBR, respectively. As shown in Figure 6, as a result of the increase in the bed porosity along the reactor from the bottom to the top. In this figure, it was observed that biomass concentration as bio-particles per unit volume of the AFBR decreased along the reactor from the bottom to the top. As shown in Figure 7, biofilm thickness increased from the bottom to the top of the reactor representing a stratification of the bio-particle in the AFBR. Stratification is a consequence of the variability of the bio-particle densities in the reactor. Also, the unequal colonization of the substratum can be one of the causes of the variability of the bio-particle densities in the reactor.

Figure 8 shows the typical pattern of particle density along the AFBR. The biofilm created on the lower levels will be, probably, more dense than that formed in the upper levels as a result of the higher pressure exerted in this zone of the reactor, and this will create denser bioparticles. In the upper part of the bed, a biofilm with a lower density and, proportionally, greater thickness will

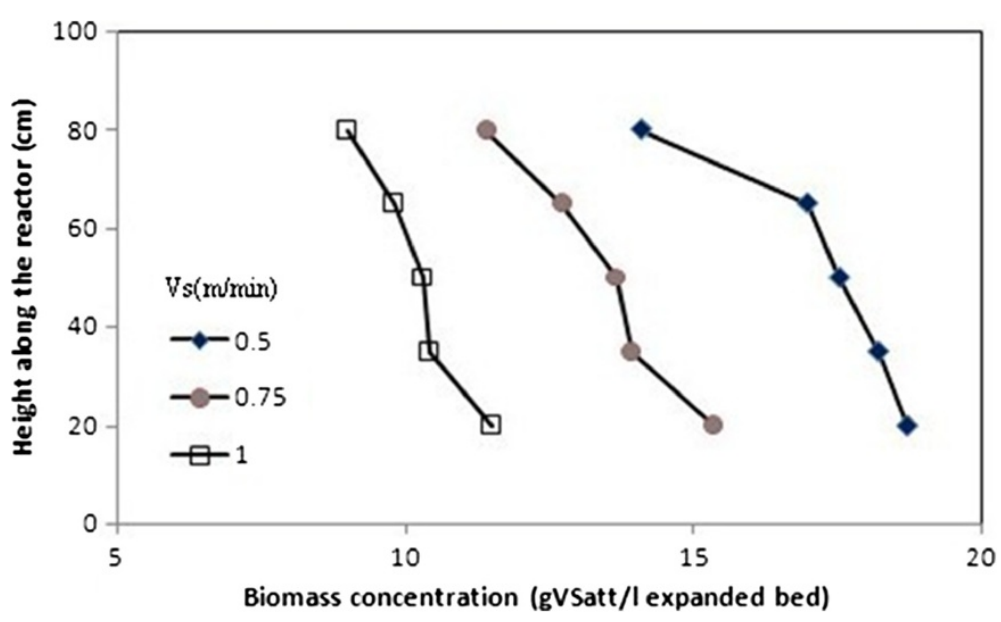

Figure 6 Profiles of biomass concentration at different upflow velocities. 


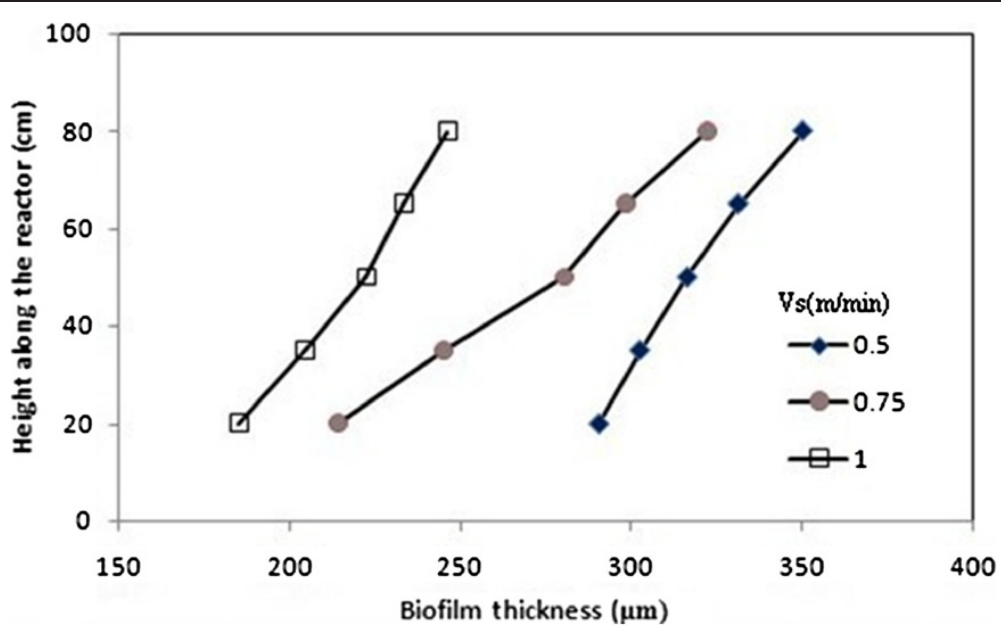

Figure 7 Profiles of biofilm thickness at different upflow velocities.

develop because of the lower pressure presented in this zone. As reported by Zhang and Bishop, the biofilm densities differ with depth within the biofilm layers for the reason that the tops of biofilm are more porous as reported by Zhang and Bishop [40]. The densities in the top layers are usually 5-10 times higher than those in the top layers, and the porosities in the top layers are in the range of $84-93 \%$, while it is in the range of $58-67 \%$ in the bottom layers [41]. The lower part of the reactor had denser bio-particles and consequently had lower bed porosity.

\section{Conclusions}

Anaerobic fluidized bed reactor with particles made of PVC as the supporting material is highly effective for COD removal for high strength wastewater from currant wastewater. The results demonstrated that the AFBR system is capable of handling an exceptionally high organic loading rate with very high removal efficiency, up to $96.6 \%$. The average biomass concentration per unit volume of the AFBR (as gVSSatt $\mathrm{L}^{-1}$ expended bed) decreased with increase in the upflow velocity at all the applied organic loading rates up to some loading rate as a result of the increase in the bed porosity. The total biomass in the reactor increased with increases in the organic loading rate. The peak biomass concentration (as gVSSatt $\mathrm{L}^{-1}$ expended bed) was observed at the bottom part of the reactor, then it droped off slowly towards the top. The biofilm thickness increased from the bottom to the top of the reactor representing a stratification of the media in the AFBR. The bed porosity increased from the bottom to the top of the reactor.

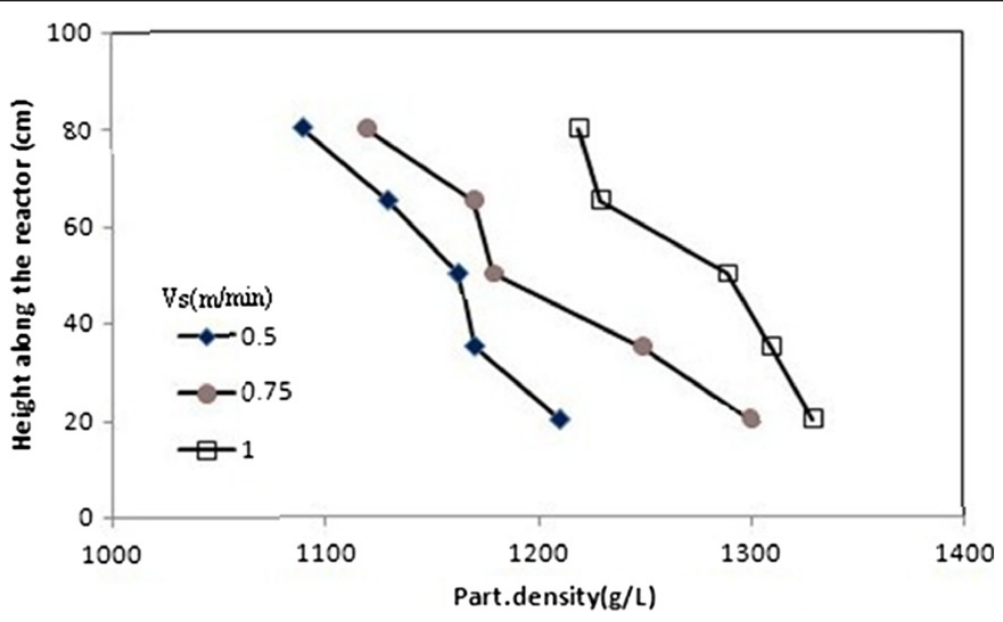

Figure 8 Profiles of particle densiy at different upflow velocities. 


\section{Competing interests}

The authors declare that they have no competing interests.

\section{Authors' contributions}

The overall implementation of this study including experimental design, data analysis and manuscript preparation were done by JJ, AHM, RN, ARM and HK. MH critically reviewed and revised the article. All authors read and approved the final manuscript.

\section{Acknowledgements}

The authors are most grateful to the laboratory staff of the Department of Environmental Health Engineering, School of Public Health, Tehran University of Medical Sciences, Iran, for their collaboration in this research.

\section{Author details}

${ }^{1}$ School of Public Health, Tehran University of Medical Sciences, Tehran, Iran. ${ }^{2}$ Department of Environmental Health Engineering, School of Public Health, Shiraz University of Medical Sciences, Shiraz, Iran. ${ }^{3}$ Health Promotion Research Center, Zahedan University of Medical Sciences, Zahedan, Iran. ${ }^{4}$ Center for Solid Waste Research, Institute for Environmental Research, Tehran University of Medical Sciences, Tehran, Iran. ${ }^{5}$ National Institute of Health Research, Tehran University of Medical Sciences, Tehran, Iran.

Received: 25 May 2014 Accepted: 29 October 2014

Published online: 25 November 2014

\section{References}

1. Mahvi A: Application of ultrasonic technology for water and wastewater treatment. Iranian J Public Health 2009, 38:1-17.

2. Karimi $\mathrm{B}$, Ehrampoush $\mathrm{MH}$, Jabary $\mathrm{H}$ : Indicator pathogens, organic matter and LAS detergent removal from wastewater by constructed subsurface wetlands. J Environ Health Sci Eng 2014, 12:52.

3. Mahvi A: Sequencing batch reactor: a promising technology in wastewater treatment. Iranian J Environ Health Sci Eng 2008, 5:79-90.

4. Naghizadeh A, Mahvi A, Vaezi F, Naddafi K: Evaluation of hollow fiber membrane bioreactor efficiency for municipal wastewater treatment. Iranian J Environ Health Sci Eng 2008, 5:257-268.

5. Rajasimman M, Karthikeyan C: Aerobic digestion of starch wastewater in a fluidized bed bioreactor with low density biomass support. J Hazard Mater 2007, 143:82-86.

6. Lohi A, Alvarez Cuenca M, Anania G, Upreti S, Wan L: Biodegradation of diesel fuel-contaminated wastewater using a three-phase fluidized bed reactor. J Hazard Mater 2008, 154:105-111.

7. Chen C-L, Wu J-H, Tseng I-C, Liang T-M, Liu W-T: Characterization of active microbes in a full-scale anaerobic fluidized bed reactor treating phenolic wastewater. Microbes Environments/JSME 2008, 24:144-153.

8. Rabah FKJ: Denitrification of high-strength nitrate wastewater using fluidizedbed biofilm reactors. City: Elsevier; 2003:3719-3728.

9. Shieh WK, Sutton P, Kos P: Predicting reactor biomass concentration in a fluidized-bed system. J Water Pollut Control Fed 1981, 1574-1584.

10. Fernandez N, Montalvo S, Borja R, Guerrero L, Sí،nchez E, Corti@s I, Colmenarejo MF, Travieso L, Raposo F: Performance evaluation of an anaerobic fluidized bed reactor with natural zeolite as support material when treating high-strength distillery wastewater. In Book Performance evaluation of an anaerobic fluidized bed reactor with natural zeolite as support material when treating high-strength distillery wastewater, Volume 33. City: Elsevier; 2008:2458-2466.

11. Haroun M, Idris A: Treatment of textile wastewater with an anaerobic fluidized bed reactor. In Book Treatment of textile wastewater with an anaerobic fluidized bed reactor, Volume 237. City: Elsevier; 2009:357-366.

12. Borja $\mathrm{R}$, Banks $\mathrm{CJ}$ : Response of an anaerobic fluidized bed reactor treating ice-cream wastewater to organic, hydraulic, temperature and $\mathrm{pH}$ shocks. In Book Response of an anaerobic fluidized bed reactor treating ice-cream wastewater to organic, hydraulic, temperature and pH shocks, Volume 39. City: Elsevier; 1995:251-259. 251-259.

13. Alvarado-Lassman A, Rustrian E, Garcia-Alvarado MA, Rodriguez-Jimenez GC, Houbron E: Brewery wastewater treatment using anaerobic inverse fluidized bed reactors. In Book Brewery wastewater treatment using anaerobic inverse fluidized bed reactors, Volume 99. City: Elsevier; 2008:3009-3015.

14. Montalvo S, Guerrero L, Borja R, Cortíos I, Sl. ‘nchez E, Colmenarejo MF: Effect of the influent COD concentration on the anaerobic digestion of winery wastewaters from grape-red and tropical fruit (guava) wine production in fluidized bed reactors with Chilean natural zeolite for biomass immobilization. Chem Biochem Eng Q 2010, 24:219-226.

15. Jafari J, Mesdaghinia A, Nabizadeh R, Farrokhi M, Mahvi AH: Investigation of Anaerobic Fluidized Bed Reactor/Aerobic Mov-ing Bed Bio Reactor (AFBR/MMBR) System for Treatment of Currant Wastewater. Iran J Public Health 2013, 42:860-867.

16. Turan M, Gulsen H, Celik MS: Treatment of landfill leachate by a combined anaerobic fluidized bed and zeolite column system. J Environ Eng 2005, 131:815-819.

17. Hobson PN, Wheatley A: Anaerobic digestion: modern theory and practice. London: Elsevier applied science; 1993.

18. Speece RE: Anaerobic biotechnology for industrial wastewater treatment. In Book Anaerobic biotechnology for industrial wastewater treatment, Volume 17. City: ACS Publications; 1983:416A-427A.

19. Kwok WK, Picioreanu C, Ong SL, Van Loosdrecht MCM, Ng WJ, Heijnen JJ: Influence of biomass production and detachment forces on biofilm structures in a biofilm airlift suspension reactor. In Book Influence of biomass production and detachment forces on biofilm structures in a biofilm airlift suspension reactor, Volume 58. City: John Wiley \& Sons; 1998:400-407.

20. Chang HT, Rittmann BE, Amar D, Heim R, Ehlinger O, Lesty Y: Biofilm detachment mechanisms in a liquid fluidized bed. In Book Biofilm detachment mechanisms in a liquid fluidized bed, Volume 38. City: Wiley Online Library; 1991:499-506. 499-506.

21. Van Loosdrecht MCM, Eikelboom D, Gjaltema A, Mulder A, Tijhuis L, Heijnen JJ: Biofilm structures. In Book Biofilm structures, Volume 32. City: Elsevier; 1995:35-43.

22. Alves CF, Melo LF, Vieira MJ: Influence of medium composition on the characteristics of a denitrifying biofilm formed by $<i>$ Alcaligenes denitrificans $</ \mathrm{i}>$ in a fluidised bed reactor. In Book Influence of medium composition on the characteristics of a denitrifying biofilm formed by $\langle i\rangle$ Alcaligenes denitrificans $</ i>$ in a fluidised bed reactor, Volume 37. City: Elsevier; 2002:837-845.

23. Koloini T, Farkas E: Fixed bed pressure drop and liquid fluidization in tapered or conical vessels. Can J Chem Eng 2009, 51:499-502.

24. Hsu H: Characteristics of tapered fluidized reactors: two phase systems. In Book Characteristics of tapered fluidized reactors: two phase systems. City: Tennessee Univ., Knoxville (USA): Dept. of Chemical, Metallurgical and Polymer Engineering; Oak Ridge National Lab., TN (USA); 1978.

25. Shi YF, Yu Y, Fan L: Incipient fluidization condition for a tapered fluidized bed. Industrial Eng Chem Fundamental 1984, 23:484-489.

26. Peng Y, Fan LT: Hydrodynamic characteristics of fluidization in liquidsolid tapered beds. In Book Hydrodynamic characteristics of fluidization in liquid-solid tapered beds, Volume 52. City: Elsevier; 1997:2277-2290.

27. Sen S, Demirer G: Anaerobic treatment of real textile wastewater with a fluidized bed reactor. Water Res 2003, 37:1868-1878.

28. Haroun $M$, Idris $A$ : Treatment of textile wastewater with an anaerobic fluidized bed reactor. Desalination 2009, 237:357-366.

29. APHA, W. AA: Standard Methods for the Examination of Water and Wastewater. In Book Standard Methods for the Examination of Water and Wastewater. City: Mc Graw Hill; 2005.

30. Schreyer HB, Coughlin RW: Effects of stratification in a fluidized bed bioreactor during treatment of metalworking wastewater. In Book Effects of stratification in a fluidized bed bioreactor during treatment of metalworking wastewater, Volume 63. City: Wiley Online Library; 1999:129-140.

31. Hidalgo M: Start-up, microbial adhesion in anaerobic fluidized bed bioreactors (Estudio de la puesta en marcha y adhesilon de microorganismos en biorreactores anaerobios de lecho fluidizado). Spain: University of Valladolid; 1999.

32. Farhan $\mathrm{MH}$, Chin Hong PH, Keenan JD, Shieh WK: Performance of Anaerobic Reactors during Pseudo Steady State Operation. J Chem Tech Biotechnol 1997, 69:45-57.

33. Koloini T, Farkas EJ: Fixed bed pressure drop and liquid fluidization in tapered or conical vessels. In Book Fixed bed pressure drop and liquid fluidization in tapered or conical vessels, Volume 51. City: Wiley Online Library; 1973:499-502.

34. García-Bernet D, Buffiere P, Elmaleh S, Moletta R: Application of the down-flow fluidized bed to the anaerobic treatment of wine distillery wastewater. Water Sci Technol 1998, 38:393-399.

35. Perez M, Romero L, Sales D: Comparative performance of high rate anaerobic thermophilic technologies treating industrial wastewater. Water Res 1998, 32:559-564. 
36. Rozzi A: Operational and control parameters in anaerobic processes. In Book Operational and control parameters in anaerobic processes. City; 1986.

37. Kato MT, Field JA, Kleerebezem R, Lettinga G: reatment of low strength soluble wastewaters in UASB reactors. In Book Treatment of low strength soluble wastewaters in UASB reactors. 77th edition. City: Elsevier; 1994:679.

38. Andalib M, Hafez H, Elbeshbishy E, Nakhla G, Zhu J: Treatment of thin stillage in a high-rate anaerobic fluidized bed bioreactor (AFBR). Bioresour Technol 2012, 121:411-418.

39. Rabah FKJ, Dahab MF: Biofilm and biomass characteristics in highperformance fluidized-bed biofilm reactors. In Book Biofilm and biomass characteristics in high-performance fluidized-bed biofilm reactors. 38th edition. City: Elsevier; 2004:4262-4270.

40. Zhang TC, Bishop PL: Density, porosity, and pore structure of biofilms. Water Research 1994, 28:2267-2277.

41. Zhang TC, Bishop PL: Structure, activity and composition of biofilms. In Book Structure, activity and composition of biofilms. 29th edition. City; 1994:335-344.

doi:10.1186/s40201-014-0139-x

Cite this article as: Jaafari et al:: Influence of upflow velocity on performance and biofilm characteristics of Anaerobic Fluidized Bed Reactor (AFBR) in treating high-strength wastewater. Journal of Environmental Health Science \& Engineering 2014 12:139.

\section{Submit your next manuscript to BioMed Central and take full advantage of:}

- Convenient online submission

- Thorough peer review

- No space constraints or color figure charges

- Immediate publication on acceptance

- Inclusion in PubMed, CAS, Scopus and Google Scholar

- Research which is freely available for redistribution 